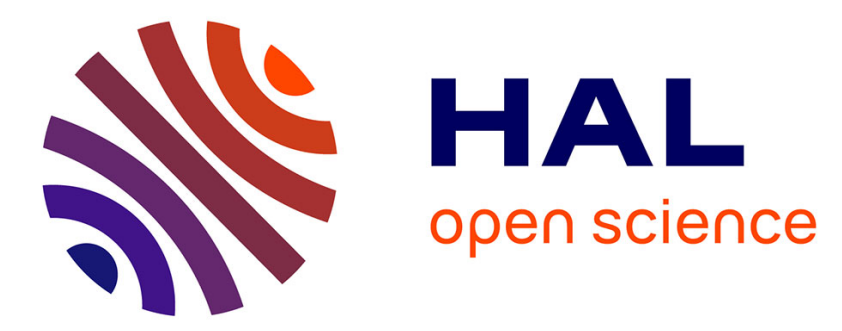

\title{
Brain acetylcholinesterase as a marine pesticide biomarker using Brazilian fishes
}

Manildo M. Oliveira, Moacelio V. Silva Filho, Vera L.F. Cunha Bastos, Flavio C. Fernandes, Jayme Cunha Bastos

\section{- To cite this version:}

Manildo M. Oliveira, Moacelio V. Silva Filho, Vera L.F. Cunha Bastos, Flavio C. Fernandes, Jayme Cunha Bastos. Brain acetylcholinesterase as a marine pesticide biomarker using Brazilian fishes. Marine Environmental Research, 2007, 63 (4), pp.303. 10.1016/j.marenvres.2006.10.002 . hal-00562960

\section{HAL Id: hal-00562960 https://hal.science/hal-00562960}

Submitted on 4 Feb 2011

HAL is a multi-disciplinary open access archive for the deposit and dissemination of scientific research documents, whether they are published or not. The documents may come from teaching and research institutions in France or abroad, or from public or private research centers.
L'archive ouverte pluridisciplinaire HAL, est destinée au dépôt et à la diffusion de documents scientifiques de niveau recherche, publiés ou non, émanant des établissements d'enseignement et de recherche français ou étrangers, des laboratoires publics ou privés. 


\section{Accepted Manuscript}

Brain acetylcholinesterase as a marine pesticide biomarker using Brazilian

fishes

Manildo M. Oliveira, Moacelio V. Silva Filho, Vera L.F. Cunha Bastos, Flavio

C. Fernandes, Jayme Cunha Bastos

PII:

S0141-1136(06)00189-9

DOI:

10.1016/j.marenvres.2006.10.002

Reference:

MERE 3070

To appear in:

Marine Environmental Research

Received Date:

13 August 2005

Revised Date:

11 June 2006

Accepted Date:

10 October 2006

Please cite this article as: Oliveira, M.M., Silva Filho, M.V., Cunha Bastos, V.L.F., Fernandes, F.C., Bastos, J.C., Brain acetylcholinesterase as a marine pesticide biomarker using Brazilian fishes, Marine Environmental Research (2006), doi: 10.1016/j.marenvres.2006.10.002

This is a PDF file of an unedited manuscript that has been accepted for publication. As a service to our customers we are providing this early version of the manuscript. The manuscript will undergo copyediting, typesetting, and review of the resulting proof before it is published in its final form. Please note that during the production process errors may be discovered which could affect the content, and all legal disclaimers that apply to the journal pertain. 


\section{Brain acetylcholinesterase as a marine pesticide biomarker using Brazilian fishes}

Manildo M. Oliveira ${ }^{\text {a }}$

Moacelio V. Silva Filho ${ }^{b}$

Vera L. F. Cunha Bastos ${ }^{c}$

Flavio C. Fernandes ${ }^{\mathrm{d}}$

Jayme Cunha Bastos ${ }^{\mathrm{c}^{*}}$

${ }^{a}$ Departamento de Biologia - Faculdade da Região dos Lagos, FERLAGOS, Cabo Frio, RJ

${ }^{\mathrm{b}}$ Fundação Oswaldo Cruz, EPSJV - LATEC, Rio de Janeiro, RJ

${ }^{\mathrm{c}}$ Departamento de Bioquímica, Instituto de Biologia Roberto Alcantara Gomes,

Universidade do Estado do Rio de Janeiro, UERJ, Rio de Janeiro, RJ

${ }^{\mathrm{d}}$ Instituto de Estudos do Mar Almirante Paulo Moreira, IEAPM, Arraial do Cabo, RJ

*Corresponding author: Av. Manoel de Abreu, 48, CEP 20550-170, Rio de Janeiro RJ,

Brazil. Tel.: +55 21 25876429; fax:+55 21 25876136. E-mail address: jbastos@uerj.br 


\section{Abstract}

Brain acetylcholinesterase (AChE) of some fishes from the coast of Rio de Janeiro state was studied as a possible pesticide biomarker in marine environmental monitoring. AChE specific activity in brain varied from 145 to $530 \mathrm{U} / \mathrm{g}$ of proteins and the MichaelisMenten constant $\left(\mathrm{K}_{\mathrm{M}}\right)$ for acetylthiocholine varied from 104 to $291 \mu \mathrm{M}$ among the twenty species studied. The enzyme sensitivity to methyl paraoxon, evaluated by the inhibition kinetic constants, shows that some species (Paralonchurus brasiliensis and Genidens genidens) are more sensitive (IC50-30 min $=455$ and $468 \mathrm{nM}$, respectively). The less sensitive Merluccius hubbsi and Percophis brasiliensis (IC50-30min =3,339 and 3,259 $\mathrm{nM}$, respectively) belong to the super-order Paracanthopterygii, which includes the more ancient species. On the other hand, more susceptible species belong to the super-order Acanthopterygii, which includes more recent species. These results suggest a possible evolutionary linkage for AChE sensitivity to methyl paraoxon. The application of inhibition kinetic constants for fish brain AChE in phylogenetic studies is still being investigated. The results have shown that a fish sentinel species should have the highest brain AChE level among the more sensitive ones.

Keywords: acetylcholinesterase, organophosphate, pollutant, biomarker. 


\section{Introduction}

Pesticides are used in agriculture to control insects and other pests, which contaminates rivers and, eventually, the sea. In addition to traditional chemical analysis, activity of the enzyme acetylcholinesterase (AChE) has been used for environmental monitoring programs (Burgeot, Bocquéné, Porte, Dimet, Santella, Garcia de la Parra et al., 1996; Huang, Obih, Jaiswal, Hartley, \& Thiyagarajah (1997); Minier, Levy, Rabel, Bocquéné, Godefroy, Burgeot et al., 2000) because AChE inhibition in tissues of fish and other animals can be used as biomarker for organophosphorous and carbamates exposure (Escartin \& Porte, 1996; Sturn, Silva de Assis, \& Hansen, 1999). Inhibition of AChE is not necessarily fatal, but using a fish with a highly sensitive AChE as a sentinel species will allow the detection of lower contamination levels.

The proper use of enzymatic biomarkers requires a fundamental understanding of its biochemistry for the species to be utilized. Vertebrate cholinesterases have been proposed to exist alternatively as globular forms or asymmetric forms associated with a collagen-containing tail (Massoulié, Pezzementi, Bon, Krejci, \& Vallette, 1993). Soluble globular forms may be nonamphiphilic or amphiphilic (Bon, Toutant, Méflah, \& Massoulié, 1988). Because asymmetric forms of vertebrate cholinesterases require highsalt buffers for solubilization, whereas amphiphilic forms require detergent for solubilization, inaccurate measurements of $\mathrm{ChE}$ activity may result from the inability to consistently and thoroughly extract the enzyme from tissue samples.

In addition, it is important to consider how environmental history and seasonal conditions affect the physiology of the sentinel species (Monserrat, Bianchini \& Bainy, 2002; Rodriguez-Fuentes \& Gold-Bouchot, 2004).

The present work is part of a marine environmental monitoring program (MOMAM) undertaken by the Instituto de Estudos do Mar Almirante Paulo Moreira (IEAPM) of the Brazilian Navy. The aim of this work was to assess the potential of brain AChE of some coastal marine fish in Rio de Janeiro State as a biomarker for organophosphates and carbamates. 


\section{Materials and Methods}

The oceanographic studies were carried out along the coast of Rio de Janeiro State, in Southeastern Brazil, as shown in Table 1 and Figure 1.

Seawater samples were collected with a Nansen bottle and assayed for dissolved oxygen, nitrate, ammonia and phosphate according to Strickland \& Parsons (1972). The salinity was measured with a density-meter model RS-23C (Beckman). The temperatures were measured with thermometers on the Nansen bottle.

The ocean specimen captures were carried out using an otter-trawl in an IEAPM boat, dragging for 20 min at 3 knots. Fish from the Sepetiba Bay were caught by fishermen with rod, line and hook. The animals were identified according to Figueiredo \& Menezes (1980) and were sacrificed in situ. Their brains were removed, rapidly bathed in a cold $0.9 \% \mathrm{NaCl}$ solution and wrapped in parafilm. Each small bag was thrown in liquid nitrogen and then kept frozen at $-20{ }^{\circ} \mathrm{C}$ in a freezer until homogenization. After being defrosted, brains were mopped up quickly with filter paper, weighed, finely chopped and suspended in a phosphate buffer $(10 \mathrm{~mL}$ of sodium phosphate buffer $0.1 \mathrm{M}, \mathrm{pH} 7.5$, per gram of wet tissue) for homogenization (30 strokes using a Potter-Elvehjem equipment) at $5^{\circ} \mathrm{C}$.

The brain AChE activity was measured in the homogenates at room temperature (25-28 $\left.{ }^{\circ} \mathrm{C}\right)$ according to Ellman, Courtney, Andres, \& Featherstone (1961) with some modifications. The final concentrations in the enzyme assay medium were: dithio-bisnitrobenzoic acid (DTNB) $0.25 \mathrm{mM}$, TRITON X-100 $0.1 \%$ and substrate $1 \mathrm{mM}$ in phosphate buffer $0.1 \mathrm{mM}, \mathrm{pH} 7.5$. The substrate was acetylthiocholine iodide (AceScol) and, when specified, replaced by propionyl (ProScol) or butyrylthiocholine iodides (ButScol) in the same concentration. The extinction coefficient of the reaction product (thionitrobenzoate ion) was $14,150 \mathrm{M}^{-1} \mathrm{~cm}^{-1}$ in the spectrophotometer UV-160A (Shimadzu) at $412 \mathrm{~nm}$. The activities are expressed in Units $(1 \mathrm{U}=1 \mu \mathrm{mol}$ of product formed per min) per gram of wet tissue or per gram of total proteins (specific activity). Five replicated assays carried out with each brain homogenate produced a coefficient of 
variation lower than $5 \%$. The total proteins were determined as described by Peterson (1977), with no precipitation step, using bovine serum albumin as standard.

The soluble AChE was determined in supernatants obtained by diluting the homogenates with phosphate buffer to $500 \mathrm{U} / \mathrm{mL}$ and centrifuging $(30,000 \times \mathrm{g} / 30 \mathrm{~min} / 4$ $\left.{ }^{\circ} \mathrm{C}\right)$. The activity of AChE remaining in the supernatant was considered as soluble AChE and expressed as percentage (\%) of the total activity. The pellets of these centrifugations were suspended in phosphate buffer with $0.1 \%$ of TRITON X-100, homogenized as described and centrifuged $\left(100,000 \times \mathrm{g} / 90 \mathrm{~min} / 4{ }^{\circ} \mathrm{C}\right)$. The supernatants were collected and pooled by species for Michaelis-Menten constant $\left(\mathrm{K}_{\mathrm{M}}\right)$ and IC50 determinations. The $\mathrm{K}_{\mathrm{M}}$ was calculated with non-linear regressions (Graph Pad Software, Inc.) with acetylthiocholine from 0.1 to $2 \mathrm{mM}$. The IC50-30min for methyl paraoxon was evaluated by the inhibition kinetic constants according to Johnson \& Wallace (1987) and Kemp \& Wallace (1990).

Phylogenetic correlations of the brain AChE specific activity among the collected species were assessed by hierarchic cluster analysis (De Ghett, 1978). The non-parametric cluster analysis of brain AChE specific activity and the Mann-Whitney test (U test) with the differences among the groups were carried out with Statistica 5.1 (Statsoft Inc.).

\section{Results}

The properties of the seawater sampled are shown in Table 2, except for station $\mathrm{F}$ where no samples were collected. Overall, 133 fishes were collected and classified into 11 families and 20 species (Table 3). The level of cerebral AChE in these species varied from 145 to $530 \mathrm{U} / \mathrm{g}$ of protein. The final results were normalized to total protein to compensate for water loss during storage. The soluble AChE varied from 21 to $42 \%$ of total activity calculated in the homogenates (Table 4).

The IC50-30 min for methyl paraoxon varied from 455 to 3,339 $\mathrm{nM}$ and the Michaelis-Menten constant $\left(\mathrm{K}_{\mathrm{M}}\right)$ for acetylthiocholine varied from 104 to $291 \mu \mathrm{M}$ for some of the species collected. The best substrate for the insoluble cerebral AChE was acetylthiocholine. Using propionyl or butyrylthiocholine values of 13 to $39 \%$ and of 1 to 
$16 \%$, respectively, were obtained in relation to the results for acetylthiocholine ( $\mathrm{P} \%$ and $\mathrm{B} \%$ in Table 5).

Figure 2 shows the result of a cluster analysis of the collected species which were separated in two groups at the level of super-order.

\section{Discussion}

Brain AChE specific activity was not influenced by the seawater physicochemical parameters. Variations of physicochemical parameters were very small and even in station $\mathrm{B}$, where the greatest variations were observed, there was no correlation between the physicochemical parameters and AChE activity (Table 2). Similarly, Olson \& Christensen (1980) studied the effect of many chemicals in muscle AChE activity in fathead minnow (Pimephales promelas) and found that nitrate above $0.01 \mathrm{M}$ caused a slight inhibition of the enzyme while phosphate and ammonium had no effect, even in concentrations above 0,01 M. In the present work, the concentrations of nitrate, phosphate and ammonium did not exceed $0.01 \mathrm{M}$ in any water sample analyzed.

However, brain AChE activity levels varied according to fish length. Pagrus pagrus, Porichthys porosissimus and Percophis brasiliensis showed the greatest correlation (Correlation Coefficient $=-0.6333,-0.7470$ and -0.80134 , respectively), all negatives, indicating that older animals have less AChE in the brain. Reportedly, this ordinary variation in AChE activity relates to the biology and ecology of each species (Bocquené, Galgani, \& Truquet, 1990). So, possible intraspecific variation in the brain AChE levels has to be evaluated to correctly interpret low results for brain AChE activity.

The variation among species, or interspecies AChE differences, might be ascribed to phylogeny according to Magnotti, Zaino, \& McConnell (1994). The authors separated the species in two groups, one of high enzymatic activity and the other of low enzymatic activity. The group with the highest activities included families of the super-order Acanthopterygii. This super-order includes the more developed species. Our results were similar. A hierarchic cluster analysis (Figure 2) made with the brain AChE specific activities of the collected fish separated them into two groups: one with two species with 
the lowest brain AChE specific activity which belong to super-order Paracanthopterygii and other including the rest of the samples. The species in this latter group, except Genidens genidens, belong to super-order Acanthopterygii, with the highest brain AChE levels. Another two species, with only one sample, were not included in this analysis (Table 3). The super-order Paracanthopterygii includes species of primitive descent, according to Nelson (1984). Our results confirm a possible linkage between the brain AChE activity levels and the phylogenetic origin of the fish.

The low soluble AChE activity found in brain of the fishes we studied (21 to 44\%) support the hypothesis that the principal activity of this enzyme in brain, like in muscle, is particulate (Massoulié, Pezzementi, Bon, Krejci \& Vallette, 1993). Our results showed that in the majority of the species studied a centrifugation step discarded up to 60 to $70 \%$ of the AChE activity (Table 4). Although several results were published using soluble AChE only (Bocquené et al, 1990; Magnotti et al, 1994; Boone \& Chambers 1997; Sturn, da Silva de Assis, \& Hansen, 1999; Flammarion, Noury \& Garric, 2002; Varò, Navarro, Amat \& Guilhermino, 2003), our findings reinforce the importance of using an AChE assay method without including a prior centrifugation step to discard pellets. So, in this report the brain AChE activity was assayed directly in the homogenates guaranteeing the detection of both enzyme activities (soluble and particulate).

The sensitivity of particulate brain AChE to methyl paraoxon varied from species to species (Table 5) and all brain AChE activities from the Neotropical fishes we studied were less sensitive to methyl paraoxon than AChE from other animals (Table 6). Moreover, less sensitive fish species, like Merluccius hubsi and Percophis brasiliensis (Table 5) exhibited low brain AChE levels (Table 4). The Correlation Coefficient between brain AChE sensitivity (IC50-30min) and brain AChE levels (AChE) for some species (Table 4) was -0.75423 . These results indicate that by selecting a sentinel species with low AChE activity levels one might risk biomarker's efficiency by selecting a species also with less sensitivity to the toxic substances.

The amount of enzyme activity is the common parameter when brain AChE is used as biomarker to pesticide exposure. A 50\% reduction in specific activity in regard to non- 
exposed individuals suggests that these toxics are present in the environment (Burgeot, Bocquéné, Porte, Dimeet, Santella, Garcia de la Parra, Pfhol-Leszkowicz, Raoux \& Galgani, 1996; Kozlovskaya \& Mayer, 1984). Bocquené, Galgani, \& Truquet (1990), working with several species of marine animals, suggested the utilization of the fish Pleuronectes platessa and the crustacean Palaemon serratus which, in comparing with others marine organisms, had the highest AChE specific activities. Besides, these species were the most sensitive organisms to the inhibitors, increasing the biomarker's efficiency.

For the Brazilian fishes studied, the sensibility to the pesticide was higher for enzymes with high $\mathrm{K}_{\mathrm{M}}$ or with low affinity for the natural substrate. The efficiency of hydrolysis of substrates with crescent alkyl chain also demonstrated that the more sensitive cerebral AChE is less specific for the natural substrate, as shown by the high values for $\mathrm{P} \%$ and $\mathrm{B} \%$ and the high $\mathrm{K}_{\mathrm{M}}$ for acetylthiocholine (Table 5). Just the inverse was observed by Kemp \& Wallace (1990) for other animals. These authors suggested that the enzyme catalytic center should be more open in more sensitive animals, making substrate and inhibitor catalysis easier. They worked with widely different groups of animals: mammals, birds and fish, but our results, just for fish, do not encompass this latter broad grouping. These results indicate that the sensitivity to the pesticides and the specificity for the substrate can involve different mechanisms in different species. Temperature can influence the $\mathrm{K}_{\mathrm{M}}$ and IC50 for the brain AChE in rat with little influence in changing the kinetic constants for this enzyme in channel catfish (Carr and Chambers, 1996), which substantiate the concept that the higher resistance of AChE to organophosphate pesticide in some fishes can involve sites other than those involved in natural substrate and pesticide catalysis.

\section{Conclusion}

In conclusion, the brain AChE levels and its sensitivity to organophosphorus in fishes of the Rio de Janeiro coast are quite variable. Further in vitro and in vivo studies on the properties of the brain AChE present in each fish species will make it easier to choose marine sentinel species as a biomarker. However, our results have shown that a sentinel Neotropical fish species should have the highest brain AChE level among the more 
sensitive ones.

\section{References}

Bocquené, G., Galgani, F., \& Truquet, P. (1990). Characterization and assay conditions for use of AChE activity form several marine species in pollution monitoring. Marine Environmental Research, 30, 75-89.

Bon, S.; Toutant, J-P.; Méflah, K.; Massoulié, J. (1988). Amphiphilic and nonamphiphilic forms of Torpedo cholinesterases: I. Solubility and Aggregation Properties. Journal of Neurochemistry, 51, 776-785.

Boone, J. S., \& Chambers, J. E. (1997). Biochemical factors contributing to toxicity differences among chlorpyrifos, parathion, and methyl parathion in mosquito fish (Gambusia Affinis). Aquatic Toxicology, 39, 333-343.

Burgeot, T., Bocquene, G., Porte, C., Dimeet, J., Santella, R. M., Garcia de la Parra, L. M., Pfhol-Leszkowicz, A., Raoux, C., \& Galgani, F. (1996). Bioindicators of pollutant exposure in the Northwestern Mediterranean Sea. Marine Ecology Progress Series, $131,125-141$.

Carr, R. L., \& Chambers, J. E. (1996). Kinetic analysis of the in vitro inhibition, aging, and reactivation of brain acetylcholinesterase from rat and channel catfish by paraoxon and chlorpyrifos-oxon. Toxicology and Applied Pharmacology, 139, 365-373.

De Ghett, V. J. (1978). Hierarchical cluster analysis. Colgan, P. W. (Ed.), Quantitative Ethology (pp. 115-144). John Wiley \& Sons: New York.

Ellman, G. L., Courtney, K. D., Andres Jr., V., \& Featherstone, R. M. (1961). A new and rapid colorimetric determination of acetylcholinesterase activity. Biochemical Pharmacology, 7, 88-95.

Escartin, E., \& Porte, C. ( 1996). Acetylcholinesterase inhibition in the crayfish procarambus clarkii exposed to fenitrothion. Ecotoxicology and Environmental Safety, $34,160-164$.

Figueiredo, J. L., \& Menezes, N. A., (1980). Manual de Peixes Marinhos do Sudeste do Brasil. Zoology Museum, Săo Paulo State University: Săo Paulo, SP - Brazil.

Flammarion, P., Noury, P., \& Garric, J. (2002). The measurement of cholinesterase activities as a biomarker in chub (Leuciscus Cephalus): the fish length should not be ignored. Environmental Pollution, 120, 325-330.

Huang, T. L., Obih, P. O., Jaiswal, R., Hartley, W. R., \& Thiyagarajah, A. (1997). Evaluation of liver and brain esterases in the spotted gar fish (Lepisosteus oculatus) as biomarkers of effect in the lower Mississippi River basin. Bulletin of Environmental Contamination and Toxicology, 58, 688-695.

Johnson, J. A., \& Wallace, K. B. (1987). Species-related differences in the inhibition of brain acetylcholinesterase by paraoxon and malaoxon. Toxicology and Applied Pharmacology, 88, 234-241.

Kemp, R. J., \& Wallace, K. B. (1990). Molecular determinants of species-selective inhibition of brain acetylcholinesterase. Toxicology and Applied Pharmacolog, 104, 246-258. 
Kozlovskaya, V. I., \& Mayer Jr, F. L. (1984). Brain acethylcholinesterase and backbone collagen in fish intoxicated with with organophosphate pesticides. Journal of Great Lakes Research, 10, 261-266.

Magnotti. R.A.Jr., Zaino, J. P., \& McConnell, R. S. (1994). Pesticide-sensitive fish muscle cholinesterases. Comparative Biochemistry and Physiology C: Pharmacology, Toxicology and Endocrinology, 108, 187-194.

Massoulié, J., Pezzementi, L., Bon, S., Krejci, E., \& Vallette, F.-M. (1993). Molecular and cellular biology of cholinesterases. Progress in Neurobiology 41, 31-91.

Minier, C., Levy, F., Rabel, D., Bocquene, G., Godefroy, D., Burgeot, T., \& Leboulenger, F. (2000). Flounder health status in the Seine Bay. A multibiomarker study. Marine Environmental Research, 50, 373-377.

Monserrat, J. M., Bianchini, A., \& Bainy, A. C. D. (2002). Kinetic and toxicological characteristics of acetylcholinesterase from the gills of oysters (Crassostrea rhizophorae) and other aquatic species. Marine Environmental Research, 54, 781-785.

Nelson, J. S. (1984). Fishes of the World (2nd Ed.). John Wiley \& Sons: New York, NY.

Olson, D. L., \& Christensen, G. M. (1980). Effects of water pollutants and other chemicals on fish acetylcholinesterase (In vitro). Environmental Research, 21, 327-335 .

Peterson, G. L. (1977). A simplification of protein assay method of Lowry et al. which is more generally applicable. Analytical Biochemistry, 83, 346-356.

Rodriguez-Fuentes, G., \& Gold-Bouchot, G. (2004). Characterization of cholinesterase activity from different tissues of Nile tilapia (Oreochromis Niloticus). Marine Environmental Research, 58, 505-509.

Strickland, J. D. H., \& Parsons, T. R., (1972). A Practical Handbook of Seawater Analysis (2nd Ed.). Fisheries Research Board of Canadá: Ottawa.

Sturn, A., Silva de Assis, H. C., \& Hansen, P.-D. (1999). Cholinesterases of marine teleost fish: enzymological characterization and potencial use in the monitoring of neurotoxic contamination. Marine Environmental Research, 47, 389-398.

Varò, I., Navarro, J. C., Amat, F., \& Guilhermino, L. (2003). Effect of Dichlorvos on Cholinesterase Activity of the European Sea Bass (Dicentrarchus Labrax). Pesticide Biochemistry and Physiology, 75, 61-72. 
Table 1

Specifications of oceanographic expeditions (letters) and littoral sampling sites (numbers) organized by expedition dates

\begin{tabular}{|c|c|c|c|c|}
\hline Station & Date & City & Longitude - Latitude & Depth (m) \\
\hline A1 & $06 / 17 / 97$ & Arraial do Cabo & $22^{\circ} 58.690^{\prime} \mathrm{S}-042^{\circ} 05.660^{\prime} \mathrm{W}$ & \\
\hline A2 & $06 / 17 / 97$ & & $23^{\circ} 00.910^{\prime} \mathrm{S}-042^{\circ} 05.970^{\prime} \mathrm{W}$ & 60.0 \\
\hline B1 & $06 / 30 / 97$ & Macaé & $22^{\circ} 21.769^{\prime} \mathrm{S}-041^{\circ} 43.630^{\prime} \mathrm{W}$ & 7.5 \\
\hline B2 & $07 / 01 / 97$ & & $22^{\circ} 24.642^{\prime} \mathrm{S}-041^{\circ} 38.103^{\prime} \mathrm{W}$ & 20.0 \\
\hline B3 & $07 / 02 / 97$ & & $22^{\circ} 26.273^{\prime} \mathrm{S}-041^{\circ} 46.680^{\prime} \mathrm{W}$ & 31.0 \\
\hline B4 & $07 / 03 / 97$ & & $22^{\circ} 26.145^{\prime} \mathrm{S}-041^{\circ} 40.000^{\prime} \mathrm{W}$ & 30.0 \\
\hline $\mathrm{C} 1$ & $08 / 20 / 97$ & Arraial do Cabo & $22^{\circ} 58.260^{\prime} \mathrm{S}-042^{\circ} 03.560^{\prime} \mathrm{W}$ & 30.0 \\
\hline $\mathrm{C} 2$ & $08 / 20 / 97$ & & $22^{\circ} 58.690^{\prime} \mathrm{S}-042^{\circ} 05.660^{\prime} \mathrm{W}$ & 45.0 \\
\hline $\mathrm{C} 3$ & $08 / 20 / 97$ & & $23^{\circ} 00.910^{\prime} \mathrm{S}-042^{\circ} 05.970^{\prime} \mathrm{W}$ & 60.0 \\
\hline D1 & $08 / 21 / 97$ & Cabo Frio & $22^{\circ} 55.103^{\prime} \mathrm{S}-042^{\circ} 00.642^{\prime} \mathrm{W}$ & 30.0 \\
\hline D2 & $08 / 21 / 97$ & & $22^{\circ} 56.738^{\prime} \mathrm{S}-041^{\circ} 58.523^{\prime} \mathrm{W}$ & 45.0 \\
\hline D3 & $08 / 21 / 97$ & & $23^{\circ} 00.102^{\prime} \mathrm{S}-041^{\circ} 53.091^{\prime} \mathrm{W}$ & 60.0 \\
\hline E1 & $09 / 29 / 97$ & Guanabara Bay & $23^{\circ} 05.189^{\prime} \mathrm{S}-043^{\circ} 08.910^{\prime} \mathrm{W}$ & 48.8 \\
\hline E2 & $09 / 30 / 97$ & Guaratiba & $23^{\circ} 07.012^{\prime} \mathrm{S}-043^{\circ} 32.310^{\prime} \mathrm{W}$ & 45.0 \\
\hline E3 & $10 / 03 / 97$ & Ilha Grande & $23^{\circ} 08.160^{\prime} \mathrm{S}-044^{\circ} 23.480^{\prime} \mathrm{W}$ & 29.0 \\
\hline $\mathrm{F} 1$ & $08 / 24 / 98$ & Sepetiba Bay & $23^{\circ} 00.000^{\prime} \mathrm{S}-043^{\circ} 45.000^{\prime} \mathrm{W}$ & 6.0 \\
\hline $\mathrm{F} 2$ & $03 / 28 / 99$ & & $23^{\circ} 00.000^{\prime} \mathrm{S}-043^{\circ} 45.000^{\prime} \mathrm{W}$ & 6.0 \\
\hline
\end{tabular}

The geographic position of the stations A-E were determined by GPS and station F was from a navigation map. 
Table 2

Physical-chemical parameters of seawater in sampling sites

\begin{tabular}{|c|c|c|c|c|c|c|}
\hline \multirow{2}{*}{ Stations ${ }^{*}$} & \multirow{2}{*}{$\begin{array}{c}\text { Temperature } \\
{ }^{\circ} \mathrm{C}\end{array}$} & \multirow{2}{*}{$\begin{array}{c}\text { Salinity } \\
\text { ppm }\end{array}$} & \multirow{2}{*}{$\begin{array}{c}\text { Oxygen } \\
\text { mL/L }\end{array}$} & \multicolumn{3}{|c|}{ Nutrients $(\mu M)$} \\
\hline & & & & $\mathrm{PO}_{4}$ & $\mathrm{NO}_{3}$ & $\mathbf{N H}_{3}$ \\
\hline $\mathrm{A} 1$ & 15.64 & 35.66 & 4.58 & 0.63 & 6.82 & 1.02 \\
\hline $\mathrm{A} 2$ & 15.54 & 35.74 & 4.56 & 0.67 & 7.26 & 1.05 \\
\hline B 1 & 22.50 & 36.16 & 6.30 & 0.46 & 0.07 & 1.17 \\
\hline B2 & 20.92 & 36.36 & 5.72 & 0.57 & 1.55 & 1.96 \\
\hline B3 & 21.86 & 36.22 & 5.89 & 0.34 & 0.38 & 0.86 \\
\hline B4 & 19.80 & 36.37 & 5.56 & 0.57 & 3.94 & 1.11 \\
\hline $\mathrm{C} 1$ & 15.88 & 35.62 & 4.32 & 0.70 & 8.22 & 0.89 \\
\hline $\mathrm{C} 2$ & 15.68 & 35.58 & 4.60 & 0.65 & 8.14 & 1.06 \\
\hline $\mathrm{C} 3$ & 15.54 & 35.56 & 4.20 & 0.65 & 8.39 & 1.10 \\
\hline D1 & 17.48 & 35.85 & 4.96 & 0.67 & 7.18 & 1.22 \\
\hline D2 & 17.60 & 85 & 4.78 & 0.64 & 6.46 & 1.53 \\
\hline D3 & 16.92 & & 4.84 & 0.66 & 7.79 & 1.07 \\
\hline $\mathrm{E} 1$ & 21.84 & nd & 4.99 & 0.66 & 3.73 & 1.20 \\
\hline $\mathrm{E} 2$ & 17.28 & nd & 4.36 & 0.54 & 3.56 & 1.09 \\
\hline E3 & 2 & nd & 4.52 & 0.33 & 0.12 & 0.99 \\
\hline
\end{tabular}

nd - not determined

*Seawater was not collected in expedition F 
Table 3

Taxonomic and distribution of the studied fishes

\begin{tabular}{|c|c|c|c|c|}
\hline Family & Species & Common names & $\mathbf{N}$ & Stations \\
\hline Ariidae & Genidens genidens & bagre-guri & 6 & F1 F2 \\
\hline Batrachoididae & Porichthys porosissimos & mamangá & 7 & B3 C2 C3 D3 E1 E2 \\
\hline Bothidae & Paralichthys patagonicus & linguado & 6 & $\mathrm{C} 1 \mathrm{C} 2 \mathrm{C} 3 \mathrm{D} 2 \mathrm{E} 2$ \\
\hline Merluccidae & Merluccius rubbsi & merluza & 12 & $\mathrm{~A} 1 \mathrm{~A} 2 \mathrm{C} 2 \mathrm{C} 3$ \\
\hline Mullidae & Mullus argentinae & trilha & 4 & A2 E2 \\
\hline Percophidae & Percophis brasiliensis & tira-vira & 6 & A1 A2 C2 E2 \\
\hline Pomadasydae & Ortopristis ruber & corcoroca & 4 & E3 \\
\hline Pomadasydae & Haemulon steindachneri & corcoroca-boca-larga & 6 & F1 F2 \\
\hline Pomatomidae & Pomatomus saltatrix & enchova & 1 & D3 \\
\hline Sciaenidae & Cynoscion striatus & pescadinha & 8 & A1 A2 D 2 \\
\hline Sciaenidae & Macrodon ancylodon & pescada-foguete & 7 & B3 B4 E3 \\
\hline Sciaenidae & Umbrina canosai & castanha & 5 & A1 D1 \\
\hline Sciaenidae & Stellifer rastr & cangoá & 10 & B 1 E3 \\
\hline Sciaenidae & Micropogonias furnieri & corvina & 3 & A1 D2 \\
\hline Sciaenidae & Paralonchurus brasiliensis & maria-luíza & 14 & B1 B2 B3 \\
\hline Sciaenidae & Cynoscion jamaicensis & goete & 3 & B3 B4 \\
\hline Sciaenidae & ticirrhus americanus & papa-terra & 8 & B4 E3 F1 F2 \\
\hline Sciaenida & Ctenociaena gracilicirrhus & cangauá & 1 & $\mathrm{D} 2$ \\
\hline Serranidae & Dules auriga & mariquita & 12 & B 1 C1 D2 E1 \\
\hline Sparidae & Pagrus pagrus & pargo-róseo & 10 & A1 A2 D3 E1 \\
\hline
\end{tabular}


Table 4

Brain AChE specific activities in the studied species (in brackets the number of animals tested)*

\begin{tabular}{|c|c|c|c|c|c|c|}
\hline \multirow{3}{*}{$\begin{array}{l}\text { Species } * * \\
\text { Porichthys porosissimos }(7)\end{array}$} & \multirow{2}{*}{$\begin{array}{c}\text { Fish length } \\
(\mathrm{cm})\end{array}$} & \multirow{2}{*}{$\begin{array}{c}\text { Brain weight } \\
\text { (mg) }\end{array}$} & \multirow{2}{*}{$\begin{array}{c}\text { Total proteins } \\
(\%)\end{array}$} & \multicolumn{3}{|c|}{ Acetylcholinesterase } \\
\hline & & & & Soluble $(\%$ & U/g wet weight & U/g proteins \\
\hline & $23 \pm 5$ & $61 \pm 32$ & $7.9 \pm 3.4$ & $32 \pm 2$ & $11.9 \pm$ & $145 \pm 39$ \\
\hline Merluccius rubbsi (12) & $22 \pm 7$ & $141 \pm 54$ & $7.8 \pm 0.8$ & & $13.0 \pm 2.1$ & $186 \pm 30$ \\
\hline Percophis brasiliensis (6) & $27 \pm 2$ & $107 \pm 87$ & $12.5 \pm 9.2$ & $27 \pm 2$ & $28.6 \pm 11.2$ & $270 \pm 70$ \\
\hline Cynoscion striatus (8) & $10 \pm 2$ & $102 \pm 28$ & $6.8 \pm 1.1$ & $30 \pm 5$ & $19.8 \pm 4.0$ & $297 \pm 56$ \\
\hline Macrodon ancylodon (7) & $22 \pm 5$ & $96 \pm 46$ & $11.8 \pm 6.3$ & $36 \pm 4$ & $33.8 \pm 17.2$ & $299 \pm 41$ \\
\hline Mullus argentinae (4) & $17 \pm 3$ & $141 \pm 9$ & $10.4 \pm 2.0$ & $32 \pm 2$ & $31.0 \pm$ & $299 \pm 60$ \\
\hline Umbrina canosai $(5)$ & $12 \pm 1$ & $65 \pm 27$ & $5.7 \pm 1.4$ & $33 \pm 9$ & $20.8 \pm 8.5$ & $355 \pm 104$ \\
\hline Stellifer rastrifer (10) & $21 \pm 2$ & $117 \pm 33$ & $7.6 \pm 3.3$ & $30 \pm 4$ & $26.7 \pm 10.9$ & $355 \pm 39$ \\
\hline Micropogonias furnieri (3) & $21 \pm 3$ & $160 \pm 27$ & $7.4 \pm 0.6$ & $36 \pm 11$ & $26.5 \pm$ & $360 \pm 94$ \\
\hline Genidens genidens (6) & $28 \pm 8$ & $572 \pm 97$ & $8.9 \pm 0.7$ & $32 \pm 5$ & $34.1 \pm 3.4$ & $376 \pm 15$ \\
\hline Paralonchurus brasiliensis (14) & $23 \pm 2$ & $140 \pm 80$ & $4.9 \pm 1.4$ & $32 \pm 6$ & $19.1 \pm 7.3$ & $389 \pm 89$ \\
\hline Cynoscion jamaicensis (10) & $18 \pm 2$ & $25 \pm 34$ & $4.9 \pm 1.1$ & $30 \pm 0$ & $19.5 \pm 4.5$ & $392 \pm 63$ \\
\hline Pagrus pagrus (10) & $13 \pm 5$ & $248 \pm 129$ & $8.9 \pm 2.0$ & $27 \pm 5$ & $34.4 \pm 8.3$ & $392 \pm 90$ \\
\hline Ortopristis ruber (4) & 27 & $109 \pm$ & $13.6 \pm 2.9$ & $40 \pm 0$ & $57.4 \pm 25.2$ & $411 \pm 106$ \\
\hline Dules auriga (12) & & $70 \pm 40$ & $7.7 \pm 2.5$ & $35 \pm 7$ & $31.2 \pm$ & $427 \pm 94$ \\
\hline Haemulon steindachneri (6) & & $214 \pm 75$ & $9.4 \pm 1.5$ & $27 \pm 6$ & $42.1 \pm 13.9$ & $443 \pm 93$ \\
\hline Menticirrhus americanus (8) & & $223 \pm 67$ & $8.3 \pm 1.6$ & $21 \pm 2$ & $38.5 \pm$ & $466 \pm 103$ \\
\hline Pomatomus saltador (1) & 16 & 88 & 4.9 & 44 & 23.8 & 482 \\
\hline Paralichthys patagonicus (6) & $22 \pm 8$ & $62 \pm 35$ & $10.6 \pm 5.5$ & $33 \pm 0$ & $53.1 \pm 29.2$ & $493 \pm 54$ \\
\hline Ctenociaena gracilicirrhus (1) & 19 & 197 & 7.2 & 41 & 38.2 & 530 \\
\hline
\end{tabular}

*the values are expressed as mean \pm standard deviation of individual replicated assays in the brain of each collected fish.

**common names, number of fish collected and catch localisation are shown in Table $3 ; 1 \mathrm{U}=1 \mu \mathrm{mol}$ of product $/ \mathrm{min}$ 
Table 5

Brain AChE kinetic characteristics of species collected in this work

\begin{tabular}{lccccc}
\hline Species & IC50-30min & $\mathbf{K}_{\mathbf{M}}$ & $\mathbf{P \%}$ & B\% & AChE \\
\hline Genidens genidens & 455 & 236 & 39 & 3 & 376 \\
Paralomchurus brasiliensis & 468 & 228 & 32 & 16 & 389 \\
Haemulon steindachneri & 1035 & 273 & 18 & 2 & 443 \\
Pagrus pagrus & 1087 & 115 & 15 & 1 & 392 \\
Menticirrhus americanus & 1579 & 291 & 20 & 1 & 435 \\
Cynoscion striatus & 1595 & 206 & 17 & 1 & 297 \\
Dules auriga & 1624 & 164 & 18 & 2 & 427 \\
Merluccius hubbsi & 3259 & 107 & 28 & nd & 186 \\
Percophis brasiliensis & 3339 & 104 & 13 & nd & 270 \\
\hline
\end{tabular}

nd - not detected

IC50-30min -Pesticide concentration which inhibits 50\% of AChE activity after $30 \mathrm{~min}$ of incubation expressed in nanomol/liter (nM)

$\mathrm{K}_{\mathrm{M}}$ - Michaellis-Menten constant with AceScol $(\mu \mathrm{M})$

$\mathrm{P} \%$ [(activity with ProScol/activity with AceScol) * 100] (\%)

$\mathrm{B} \%$ [(activity with ButScol/activity with AceScol) * 100] (\%)

AChE - Specific activity of AChE in the brain (U/g protein, from Table 4) 
Table 6

Brain AChE sensitivity to organophosphates in various animals

\begin{tabular}{llcl}
\hline Organism & Pesticide & $\begin{array}{c}\text { IC50-30min } \\
(\mathbf{n M})\end{array}$ & Reference \\
\hline rat $\left(37^{\circ} \mathrm{C}\right)$ & Ethyl paraoxon & 13 & Johnson \& Wallace, 1987 \\
& Methyl paraoxon & 29 & Kemp \& Wallace, 1990 \\
& Ethyl paraoxon & 27 & Carr \& Chambers, 1996 \\
hem $\left(37^{\circ} \mathrm{C}\right)$ & Ethyl paraoxon & 37 & Kemp \& Wallace, 1990 \\
fish $($ Limanda limanda $)$ & Ethyl paraoxon & 312 & Sturn et al., 1999 \\
fish $($ Serranus cabrilla $)$ & Ethyl paraoxon & 1,925 & Sturn et al., 1999 \\
fish (rainbow trout at $\left.11^{\circ} \mathrm{C}\right)$ & Methyl paraoxon & 3,310 & Johnson \& Wallace, 1987 \\
\hline
\end{tabular}

IC50 - Pesticide concentration which inhibit 50\% of AChE activity after 30 min of "in vitro" incubation expressed in nanomol/liter (nM) 


\section{Legends of Figures}

\section{Figure 1}

Sampling sites of the expeditions (A to F) in the Rio de Janeiro state coast

\section{Figure 2}

Diagram of the hierarchic clusters analysis (Statistica $5.0^{\mathrm{A}}$, StatSoft, Inc.) for brain AChE activity of fish collected (simple linkage distance).

(1) Porichthys porosissimos; (2) Merluccius rubbsi; (3) Percophis brasiliensis; (4)

Cynoscion striatus; (5) Macrodon ancylodon; (6) Mullus argentinae; (7) Umbrina canosai;

(8) Stellifer rastrifer; (9) Micropogonias furnieri; (10) Genidens genidens; (11)

Paralonchurus brasiliensis; (12) Cynoscion jamaicensis; (13) Pagrus pagrus; (14)

Ortopristis ruber; (15) Dules auriga; (16) Haemulon steindachneri; (17) Menticirrhus

americanus; (19) Paralichthys patagonicus. The species Pomatomus saltador (18) and

Ctenociaena gracilicirrhus (20) were not included because only one sample was collected.

The number in parenthesis represents the order of these species in relation to their AChE specific activity shown in the Table 4. 
Fig 1

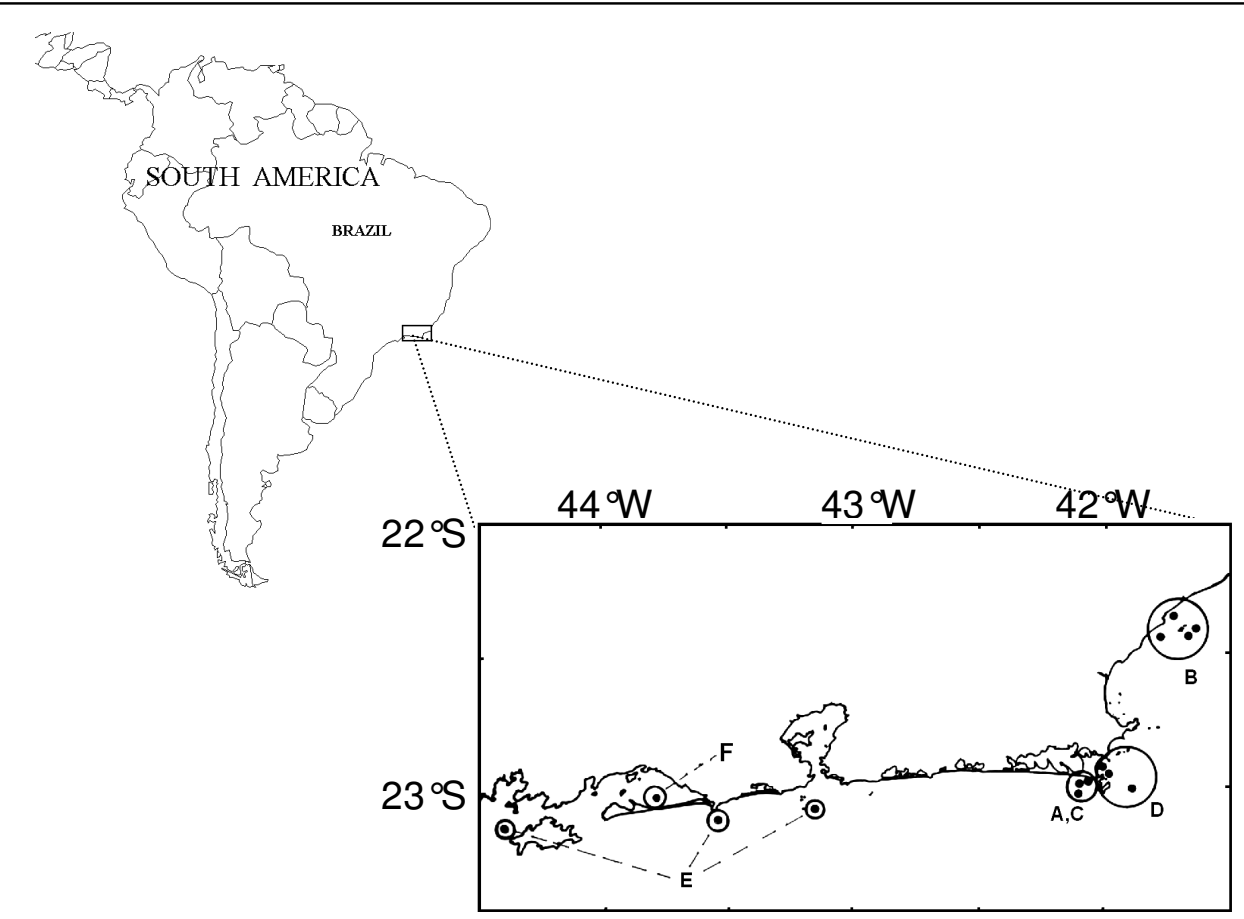


Fig 2

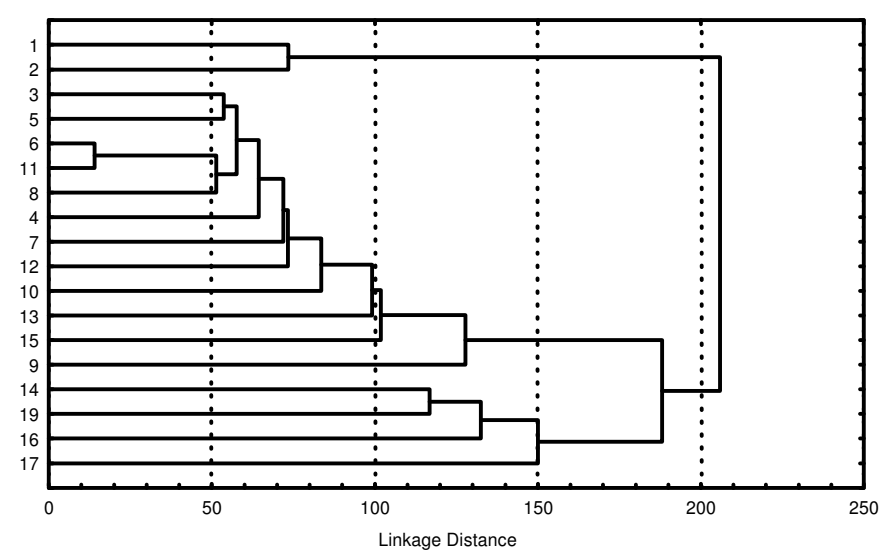

